\title{
Communication with young people through normatively fixed dialogue institutions in the regions of Russia
}

\section{E. A. Isaeva ${ }^{1}$}

${ }^{1}$ P. G. Demidov Yaroslavl State University, 14 Sovetskaya str., Yaroslavl 150003, Russian Federation

DOI: $10.18255 / 1996-5648-2021-4-552-559$

Research article Full text in Russian

The study of the regional legislation of 85 constituent entities of the Russian Federation was carried out by the author in order to identify the normatively fixed channels of communication between the state and youth at the regional level, which could make it possible through formalized institutions to carry out dialogue interaction, stimulate the desire of young people to participate in the life of society, participate in the development of the agenda in the constituent entity of Russia.

As a result, the author comes to the conclusion that the created youth governments, youth parliaments, youth public chambers and other similar institutions in the regions are not a sufficient channel for full-fledged communication with young people. Formalized platforms involve rather loyal youth in a dialogue with the authorities, leaving behind those whose opinion, attitude to the political, economic, and social decisions taken by the authorities is sometimes quite critical.

Keywords: youth, dialogue platforms, intersectoral interaction, youth civic engagement management

\section{INFORMATION ABOUT AUTHORS}

\author{
Isaeva, Elena A. $\mid$ E-mail:elenia2000@mail.ru \\ Cand. Sc. (Jurisprudence), Associate Professor
}

Funding: RFBR and EISI, Project No. 21-011-31770. 


\section{Коммуникация с молодежью \\ через нормативно закрепленные \\ диалоговые институты \\ в регионах России}

Е. А. Исаева ${ }^{1}$

${ }^{1}$ Ярославский государственный университет им. П. Г. Демидова, ул. Советская, 14 , Ярославль, 150003, Российская Федерация

DOI: 10.18255/1996-5648-2021-4-552-559

Удк 321

Научная статья

Полный текст на русском языке

Исследование регионального законодательства 85 субъектов Российской Федерации проводилось автором с целью выявления нормативно закрепленных каналов коммуникации государства с молодежью на региональном уровне, которые бы могли давать возможность через формализованные институты осуществлять диалоговое взаимодействие, стимулировать желание молодых людей участвовать в жизни общества, выработке повестки в субъекте РФ.

В результате автор приходит к выводу, что созданные молодежные правительства, молодежные парламенты, молодежные общественные палаты и иные подобные институты в регионах не являются достаточным каналом для полноценной коммуникации с молодежью. Формализованные площадки вовлекают в диалог с властью скорее лояльную молодежь, оставляя за рамками тех, чье мнение относительно принимаемых политических, экономических, социальных решений органов власти порой довольно критично.

Ключевые слова: молодежь; диалоговые площадки; межсекторное взаимодействие; управление; гражданская активность

\section{ИНФОРМАЦИЯ ОБ АВТОРАХ}

Исаева, Елена Александровна

E-mail:elenia2000@mail.ru

Кандидат юридических наук, доцент

Финансирование: РФФИ и ЭИСИ, проект № 21-011-31770 «Возможности и угрозы управления лояльностью молодежи в современной России». 
Исаева Е. А.

Одной из целей молодежной политики в России, определенной в ФЗ от 30.12.2020 N 489-ФЗ «О молодежной политике в Российской Федерации» является создание условий для участия молодежи в политической, социально-экономической, научной, спортивной и культурной жизни общества. Одним из каналов участия является совокупность диалоговых площадок, создаваемых для молодежи как на федеральном, так и региональном уровнях. $K$ числу наиболее распространенных формализованных институций относятся молодежные парламенты (молодежные палаты), молодежные правительства, молодежные советы при органах исполнительной власти субъектов России.

Наше исследование нормативной базы 85 регионов России показало, что правовую основу для существования подобные площадки имеют подавляющее большинство субъектов. При этом в каких-то регионах есть нормативная основа для создания и деятельности и молодежного правительства и молодежного парламента (Нижегородская, Костромская, Орловская, Тамбовская, Вологодская, Ленинградская, Новгородская области, республики Коми, Марий-Эл и др.); в других - нормативный акцент сделан на какую-то одну из перечисленных форм взаимодействия (Московская, Тульская, Архангельская области, НАО, республики Башкортостан и др.); в третьих - нормативная база для формализованного политического диалога не была выявлена либо при наличии правовой базы исследуемые институты фрактически не созданы. Об этом свидетельствуют, в частности, нормативные акты, регламентирующие деятельность молодежного правительства, в которые не вносились изменения с 2009 года (Воронежская область), с 2012 года (Ивановская область, Карачаево-Черкесская республика), с 2014 года (Калининградская область) и др.

Если говорить о каналах вовлечения молодежи, создания диалога с молодежными сообществами, что так необходимо для построения открытой системы гражданского общества [1, с. 113], то важными показателями являются, на наш взгляд: охват молодежи через формализованные каналы, частота коммуникаций, возможность использования канала для трансляции смыслов одной стороной и получения обратного сигнала от другой, наличие барьеров для диалога. Эти моменты также подвергались анализу в рамках проведенного исследования.

Одним из наиболее распространенных механизмов вовлечения молодежи в процесс социально-экономического развития региона, создания целостной системы отбора, подготовки и приобщения социально активных молодых людей к управленческой деятельности, повышения их правовой и политической культуры является молодежное правительство. Оно может создаваться как постоянно действующий совещательный орган при главе региона, как, например, в Вологодской, Кемеровской областях, при Правительстве субъекта, как, например, в Ленинградской, Нижегород- 
Коммуникация с молодежью через нормативно закрепленные диалоговые институты...

ской областях. Также возможен вариант, когда молодежное правительство является консультативным органом одновременно при Главе и Правительстве, как в Чеченской Республике. В ЯНАО председателем молодежного правительства является сам Губернатор автономного округа.

В каких-то регионах, например в Смоленской области, НАО, подобный орган может носить название молодежного совета (Смоленская область) или молодежной администрации (НАО), а также молодежного экспертного совета (молодежное правительство дублеров) (Красноярский край), но из содержания нормативных актов понятно, что фрункционал данных постоянно действующих совещательных органов аналогичен молодежному правительству.

Нормативные акты регионов, регламентирующие формирование и деятельность молодежных правительств, по содержанию очень схожи. Есть некоторые отличия, например, в плане требуемого возраста кандидатов: от 14 до 35 лет (Ульяновская область, Кемеровская область - Кузбасс, Чувашская республика), от 16 до 35 лет (Сахалинская область), от 20 до 30 лет (Костромская область), от 18 до 25 (Новгородская область), от 18 до 30 лет включительно (Брянская, Кировская, Смоленская, Нижегородская области, Новосибирская области, Алтайский край, республика Хакасия, Чеченская республика), от 18 до 35 лет включительно (Амурская, Астраханская, Ленинградская, Владимирская области). Есть примеры установления разного возраста для членов молодежного правительства: в НАО возрастные рамки от 18 до 30 лет не распространяются на председателя, заместителя председателя и секретаря.

Региональная нормативная база зачастую не устанавливает четкой численности членов молодежного правительства, увязывая ее с количеством созданных в субъекте профильных министерств, департаментов, либо отдает на откуп субъекту, имеющему полномочия на итоговое согласование победителей конкурса. Но есть субъекты, изначально определившие предельное число будущих членов молодежного правительства либо через указание четкой цифры, либо ее предельного значения: 14 членов (ЯНАО), не более 15 человек (Ленинградская область), 15 человек (Омская, Новгородская области), не более 19 человек (Вологодская область), 20 членов (Владимирская область, Ставропольский край), не более 20 членов (Орловская область), не более 25 человек (Магаданская область), 21 человек (Алтайский край), не более 30 человек (Смоленская область), 35 человек (Тамбовская область), не более 40 человек (Хабаровский край).

Согласно статистике охвата молодежным правительством активной молодежи, можно сделать вывод скорее о точечной, не массовой работе диалоговой площадки с молодым населением региона. Причем члены и кандидаты в члены молодежных правительств - уже изначально мотивированные, активные, скорее успешные в той или иной сорере молодые люди. 
Исаева Е. А.

В Нижегородской области для вовлечения большего числа молодежи создан Совет по делам молодежи при молодежном правительстве. Он работает как открытая площадка коммуникации молодежных министров с молодежью в целях обеспечения их участия в управлении государственными и общественными делами через проведение консультаций, предварительного обсуждения инициатив и проектов, отнесенных к компетенции министерств, а также осуществления общественного контроля за эффективностью деятельности молодежного правительства. Совет не имеет фриксированного членства. $K$ участию в заседаниях Совета приглашаются граждане в возрасте от 14 до 35 лет включительно. Данную практику расширения молодежного охвата можно оценить как положительную.

Как правило, нормативные акты закрепляют определённые схожие требования и ограничения к кандидатам в члены молодежного правительства. Практически повсеместным является требование о постоянном проживании на территории субъекта, наличие опыта создания и реализации социальных проектов. Но есть и специфические требования, к примеру подключение учетной записи в АИС «Молодежь России» (Свердловская, Владимирская области), обучение на момент конкурса в образовательных организациях высшего образования либо членство в детских или молодежных общественных организациях и объединениях (Костромская область); обучение в образовательных организациях или работа в организациях, зарегистрированных на территории субъекта или регистрация в качестве индивидуального предпринимателя на территории региона (Магаданская область); в Нижегородской области не могут быть кандидатами представители законодательных органов государственной власти и местного самоуправления, а также консультативно-совещательных органов при законодательных органах государственной власти и местного самоуправления; в Свердловской области участниками конкурса не могут являться лица, замещавшие должности членов молодежного правительства более двух сроков полномочий молодежного правительства, а также лица, являющиеся депутатами молодежного парламента Свердловской области или членами молодежной избирательной комиссии Свердловской области.

Срок полномочий молодежного правительства в регионах, как правило, составляет два года, но есть исключения, к примеру в Орловской области три года, Кемеровской области - Кузбассе - один год.

Заседания молодежных правительств предусмотрены к проведению не реже 1 раза в квартал, но есть регионы, в частности Ульяновская область, республика Хакасия, где подобные заседания должны проводиться ежемесячно, и регионы, в частности Красноярский край, где заседания молодежного органа должны проводиться не реже двух раз в год. 
Коммуникация с молодежью через нормативно закрепленные диалоговые институты...

Есть примеры нормативного ограничения по количеству сроков участия в правительстве. В частности, в Свердловской, Смоленской, Вологодской областях одно и то же лицо не может занимать должность члена молодежного правительства более двух сроков.

В целях создания условий для включения молодежи в социально-экономическую, политическую и культурную жизнь и содействия формированию осознанной и активной гражданской позиции у молодежи уже по линии законодательных органов, по примеру Общественной молодежной палаты при Государственной Думе Федерального Собрания Российской Федерации и Палаты молодых законодателей при Совете Федерации Федерального Собрания Российской Федерации, в регионах создаются молодежные парламенты. По сравнению с молодежными правительствами данные площадки уже, как правило, более многочисленные: 100 членов (республика Татарстан), 70 членов (Республика Саха (Якутия), 61 член (Нижегородская область), 60 членов (Удмуртская республика), 55 членов (Вологодская область), 52 члена (Тверская область), 50 членов (Белгородская, Самарская область, Ставропольский край), 45 членов (Брянская область), 40 человек (Волгоградская область), 38 членов (Иркутская область), 36 членов (Амурская область), 35 членов (республика Башкортостан), 34 члена (республика Марий Эл, Липецкая область), 30 членов (Оренбургская, Сахалинская, Томская области, республика Коми), 26 членов (республика Тыва), 25 членов (республика Хакасия), 24 члена (Севастополь), 23 члена (республика Алтай) и др.

По возрастному критерию для членов молодежных парламентов отличий от рамок, установленных в нормативной базе о молодежных правительствах регионов, практически нет: 18-35 лет (Белгородская, Брянская, Волгоградская, Московская, Сахалинская, Томская, Тверская области, республики Хакасия, Тыва, Коми, Адыгея и др.); 18-30 лет (Иркутская, Нижегородская области, республики Крым, Татарстан и др.); 18-31 год (Удмуртская республика и др.); 18-32 года (Камчатский край и др.); 14-30 лет (республики Саха (Якутия) и др.); 14-35 лет (Алтайский край, республика Марий Эл и др.); 16-30 лет (Воронежская область, республика Башкортостан и др.); 16-35 лет (Оренбургская, Амурская, Волгоградская области, республика Алтай и др.).

По срокам полномочий молодежные правительства и молодежные парламенты также не имеют особых расхождений. Формируются молодежные парламенты на 2 года в Белгородской, Московской, Сахалинской областях, республиках Алтай, Крым, Удмуртской республике, Севастополе; на 2,5 года - в Брянской области; на 3 года - в Иркутской, Томской областях, республиках Башкортостан, Алтай; на 5 лет - в республике Адыгея, Липецкой области. В ряде регионов, например в Алтайском крае, Волгоградской, Воронежской областях, республиках Хакасия, Тыва, Коми, Та- 
Исаева Е. А.

тарстан, XMAO и др., молодежный парламент создается на срок полномочий законодательного органа власти субъекта.

Сессии молодежного парламента созываются по мере необходимости, но не реже одного раза в полгода (Алтайский, Камчатский края, Вологодская область), два раза в год (республики Хакасия, Тыва, Ставропольский край, Амурская, Тверская области), четыре раза в год (республики Башкортостан, Крым, Адыгея, Саха (Якутия), Брянская, Иркутская, Московская, Томская, Липецкая, Нижегородская области), не реже трех раз в год (XMAO), не реже 1 раза в 4 месяца (Сахалинская область), по мере необходимости (республика Коми).

Проведенное исследование показало, что буквально в единичных субъектах есть опыт создания тематических молодежных советов при органах власти. В качестве выявленных примеров можно отметить молодежный общественный совет при департаменте культуры Воронежской области; молодежный совет департамента спорта города Москвы; молодежный совет департамента инвестиционной и промышленной политики города Москвы; молодежный совет департамента фринансов Вологодской области; молодежный совет при Министерстве образования и науки Республики Башкортостан; молодежный совет при Министерстве здравоохранения Республики Башкортостан; молодежный совет при Государственном комитете Республики Татарстан по архивному делу; общественный молодежный совет при Министерстве сельского хозяйства Республики Алтай; молодежный координационный совет по патриотическому воспитанию молодежи Республики Саха (Якутия) при Министерстве по делам молодежи и семейной политике Республики Саха (Якутия).

Все представленные выше площадки: молодежные правительства, молодежные парламенты, молодежные советы при органах власти в субъектах России - специфичны: по сути, они изначально ориентированы на вовлечение малого количества уже успешной, интеллектуально подкованной, активной молодежи. И при хорошо поставленной работе данные институции способны дать ожидаемый от них позитивный социальный эфроект для коммуникации. Но проблема в том, что, кроме упомянутых и охарактеризованных выше, в регионах нет иных нормативно закреплённых каналов взаимодействия с молодежью, которые бы могли вовлечь в системную коммуникацию широкие и разные по взглядам, интересам слои школьников, студентов, работающей молодежи и др. [2, с. 200].

Отсутствие стабильных, разнообразных, в том числе формализованных, каналов коммуникации органов власти с молодежью региона, дающих возможность услышать, почувствовать настроения молодых людей, серьезным образом влияет, на наш взгляд, на возможность реализации управленческих процессов [3, с. 151], выработки правильного вектора мероприятий молодежной политики [4, с. 039]. Даже созданные молодежные 
правительства, молодежные парламенты, молодежные советы в тех регионах, где они работают, точно не являются достаточным каналом для коммуникации с молодежью. Формализованные каналы вовлекают в диалог с властью скорее лояльную молодежь, оставляя за бортом тех, чье отношение к принимаемым политическим, экономическим, социальным решениям органами власти порой довольно критично. Создание площадок и каналов, позволяющих работать с такой молодежью в регионе, является обязательным элементом реализации молодежной политики [5, с. 21], ставящей целью формирование системы нравственных и смысловых ориентиров, позволяющих противостоять идеологии экстремизма, национализма, проявлениям ксенофробии, коррупции, дискриминации по признакам социальной, религиозной, расовой, национальной принадлежности и другим негативным социальным явлениям [6-7].

\section{Ссылки}

1. Соколов А. В., Исаева Е. А. Гражданское общество в региональном измерении // Власть. 2015. № 1. С. 113-117.

2. Сергеев А. К., Гнатюк М. А., Гнатюк К. Ю. Молодежный парламент как форма реализации региональной молодежной политики: опыт Самарской области // Государственное и муниципальное управление: Ученые записки. 2018. № 2. C. 199-204.

3. Фролов А. А., Палагичева А. В. Роль государства в управлении гражданской активностью: (по результатам исследования, проведенного в Ярославской области // Социальные и гуманитарные знания. 2017. Т. 3, № 2(10). С. 149-154.

4. Исаева Е. А. Нормативно закрепленные диалоговые площадки власти и общества в субъектах России: предпосылки эффрективности // Власть. 2013. № 8. C. $39-41$.

5. Головин Ю. А. Государственное управление развитием гражданской активности молодежи (по опыту Ярославской области) // Youth World Politic. 2016. № 1. С. 20-23.

6. Исаева Е. А., Соколов А. В., Тарусина Н. Н. О тенденциях гражданской активности: благодаря и вопреки праву // Вестник Ярославского государственного университета им. П. Г. Демидова. Серия Гуманитарные науки. 2015. № 3 (33). C. 59-64.

7. Исаева Е. А., Соколов А. В., Тарусина Н. Н. Гражданская активность россиян: тенденции законодательства и общественной практики // Социально-юридическая тетрадь. 2015. № 5. С. 130-148. 